\title{
POVERTY, BIOETHICS AND RESEARCH
}

Cléa Regina de Oliveira Ribeiro ${ }^{1}$

Elma Lourdes Campos Pavone Zoboli ${ }^{2}$

Ribeiro CRO, Zoboli ELCP. Poverty, bioethics and research. Rev Latino-am Enfermagem 2007 setembro-outubro; 15(número especial):843-9.

The article presents a reflection on conception of poverty as a condition or circumstance that restricts personal autonomy and increases vulnerability. Focusing on bioethical arguments, the authors discuss two perspectives: (i) economic, that relates poverty to incapacity to work and (ii) ethical-philosophical, which relates poverty to inequality and injustice. The first perspective corresponds to the World Bank's view according to its recommendations to the political and economic adjustment in Latin America. The second one is based on concepts of fairness and equality as components of social justice. The subjects' autonomy and vulnerability have been under question in an international movement that requests revision of ethical guidelines for the biomedical research. The bioethical arguments presented in this article enhance a discussion on unfair treatment to subjects enlisted in protocols sponsored by rich countries and hosted by poor nations.

DESCRIPTORS: bioethics; poverty; social inequity; biomedical research; vulnerability; equity; personal autonomy

\section{POBREZA, BIOÉTICA E INVESTIGACIÓN}

Nos proponemos desarrollar una reflexión bioética acerca de la concepción de la pobreza como condición o circunstancia de restricción y vulnerabilidad. Esta concepción presentará dos perspectivas: la económica, relacionada con la incapacidad (visión del Banco Mundial desde las recomendaciones políticas para el ajuste económico de los países latinoamericanos) y la ético-filosófica, relacionada con la desigualdad (basada en los conceptos de equidad e igualdad como desdoblamientos de la idea de justicia). Una de las graves consecuencias de lo anterior es el tratamiento injusto, respecto a los procedimientos de investigación, de los países ricos que reclutan las poblaciones de los países pobres como campo experimental para investigaciones en el área de la salud. Este hecho se produce principalmente en las investigaciones biomédicas o farmacológicas, cuestionando así desde el punto de vista ético el carácter de vulnerabilidad y autonomía de los individuos.

DESCRIPTORES: bioética; pobreza; inequidad social; investigación biomédica; vulnerabilidad; equidad; autonomía personal

\section{POBREZA, BIOÉTICA E PESQUISA}

Realiza-se, aqui, reflexão bioética sobre a concepção de pobreza enquanto condição, ou circunstância, de restrição e vulnerabilidade. Tal concepção prevê duas perspectivas: a econômica que relaciona pobreza com incapacidade (visão do Banco Mundial, a partir das recomendações políticas para o ajuste econômico dos países latino-americanos) e a ético-filosófica, relacionando pobreza com desigualdade (fundamentada nos conceitos de eqüidade e igualdade, enquanto desdobramentos da idéia de justiça). Uma das graves conseqüências é o tratamento injusto, no que diz respeito aos procedimentos de pesquisa dos países ricos que recrutam populações de países pobres como campo experimental para investigações na área da saúde, principalmente pesquisas biomédicas ou farmacêuticas, colocando sob questionamento ético o caráter de vulnerabilidade e autonomia desses indivíduos.

DESCRITORES: bioética; pobreza; iniqüidade social; pesquisa biomédica; vulnerabilidade; eqüidade; autonomia pessoal

${ }^{1}$ Philosophy, PhD Doctor University of São Paulo at Ribeirão Preto, College of Nursing, WHO Collaborating Center for Nursing Research Development, Brazil, e-mail: clearib@eerp.usp.br; ${ }^{2}$ RN, PhD Professor, University of São Paulo at Ribeirão Preto, College of Nursing, WHO Collaborating Center for Nursing Research Development, Brazil, e-mail: elma@usp.br 


\section{THE CURRENT CONTEXT OF POVERTY}

Poverty is not a phenomenon of our times. In the history of humanity, it can be found in different ages. But the context and conditions in which we face it today are peculiar. They involve a complex combination of economic, political, social and cultural factors against the background of capitalism and its developments, permitting the construction of a poverty concept based on conjectural conditions.

Three pillars might constitute the base for a possible understanding of the poverty situation, specifically considering Latin American developing countries: the neoliberal policty, the international economic entities (World Bank and IMF) and the people marginalized from the labor world. Involved in their external debts, these countries remain in a renegotiation regime, under conditions imposed by the World Bank reports. This type of policy results in: economic crisis, social exclusion and lack of investment in the productive sector ${ }^{(1)}$.

The road leading to these results can be traced back the crisis of the Welfare State, which happened in the 1970's for most developed countries. This model was succeeded by neoliberalism. Established little by little, it entails important modifications, such as the drastic retraction of the State to the detriment of the markets' predominant role in the development process - the minimal State - whose role becomes that of supporter and facilitator in view of market flexibilization, and no longer that of central development pole.

Latin American countries go through this crisis in the 1980's. At that time, Brazil goes through the developmentalism crisis (which leads to foreign indebtedness), stimulating a debt renegotiation process with the above mentioned international entities. However, sooner or later, all countries end up adopting the "neoliberal recipe". One of the groundbreaking practices in Latin America in line with these ideas were the measures adopted to contain and solve Chile's internal crisis, which were: strong deregulation, huge unemployment, union repression, income redistribution in favor of the rich, privatization of public goods.

In view of this picture of stagnation, combined with a strong inflation process, a set of measures arises that is called the Washington Consensus (1989) ${ }^{(1)}$, soon adopted by the World Bank and the IMF as a list that Latin American countries had to comply with as a solution to the crisis and as determinants of debt negotiations.

Considering this panorama, it should be appointed that one of the issues questioned was these countries' governability. Dependent and, therefore, without options, they transferred the decision about economic and social policies to international entities. Some analysts understood this issue as one of the facets of what was considered a minimal State.

Besides the crisis, these results meant social exclusion and lack of investments in the productive sector. Fiscal adjustments entailed a great increase in unemployment and informal work, and one of the causes of impoverishment is that a large part of the 'productive population was no longer in a formal work situation.

From the ethical perspective, the poverty condition can be seen as the result of an unfair distribution of goods, benefits and resources. The justice concept was first conceived by Aristotle in Ancient Greece. In current times, this concept was recovered and mainly inserted in the debate on political and economic philosophy, exerting a strong influence among specialists and scientists dedicated to income and resource distribution, globalization, ethics and bioethics or, in general, to the discussion about poverty and wealth in the current world.

Poverty is a form of vulnerability, as people lose the slightest conditions to live and survive. Moreover, these circumstances favor a situation of lack of dignity for people who often have no way of escaping from exploration, such as research subjects recruited in developing countries to participate in clinical trials for new drugs, in exchange for money to pay for their unattended needs - neither by society nor by the State.

This article aims to develop a bioethical reflection about the relation between these issues, given that not only citizens have faced restricted work and social care opportunities but, in a broader perspective, human life as such has lost its intrinsic value.

\section{THE ECONOMIC PERSPECTIVE OF POVERTY: INABILITY}

Considering the conditions presented above, the World Bank reports are concerned with issuing measures to fight poverty. According to the 1990 
reports, a poverty conception can be inferred on the basis of a certain social order outlined in these documents $^{(1)}$. In this order, two points are important: the minimal State and the labor world. The first should guarantee and create conditions for effective market action (renewal of institutions for this end, regulatory regime to guarantee competition, elimination of corruption, security of property rights, provision of some few social needs).

Regarding labor world, it is no longer divided in employed and unemployed. It is characterized on the one hand by "individuals who succeed to manage in the market - which is supposed to be society's most effective functioning mechanism - and on the other by individuals incapable to get into the market - the poor - which the State should help through its residual and focalizing social policies". This consideration is expressed in the 1990 reports and permits defining poverty as the "inability to reach a minimum living standard"$^{\prime(1)}$

But what is understood as a minimum living standard and what is inability?

According to the World Bank, the minimum living standard refers to consumption, that is, the minimum amount spent for nutrition and other needs, including a small part for leisure (fun and social life). This amount should be calculated in accordance with each country and region. If a person does not gain enough money to fulfill these needs, (s)he is considered poor; that is, is in no conditions to live minimally well. Moreover, inability also points towards the need for economic opportunities and social service delivery. In order to fight poverty, the State should plan policies in these two areas, favoring new economic opportunities to obtain revenues, besides assistance in health and education (social services).

This poverty concept is constructed for a labor world, in which the worker is competitive and has a job (and can find a new one if (s)he loses it) and who does not have a job is not able to. The critique is that the poor, because they are unable, are seen as losers and, hence, to them is left only the integration into the social policies offered to provide for their "inability".

One of the critical issues to be taken into account is that the minimal State's action is a step back from the perspective of social rights. In first place, because it is established as a charity and auxiliary mechanism and, second, because these rights are no longer democratically extended to all. However, the needy (even with productive capacity) have no way of choosing, unless accept. Perceived as such, their right to choose is restricted to good intentions, infringing people's citizenship and individual liberty. Hence, the poverty conception presupposed in the current international policy can be interpreted as strengthening exclusion and marginality.

\section{ETHICAL-PHILOSOPHICAL PERSPECTIVE OF POVERTY: INEQUALITY}

The idea of inequality can be inferred from Aristotle's classical text on justice ${ }^{(2)}$, which examines the notions of equality and equity. According to this author, justice is a relation in which human actions are mutually involved. Some of these relations refer to honor, money or security, while others involve attitudes or "objects to which the good (virtuous) man relates with". Both types of relation are ruled by the idea of distribution, that is, sharing or exchanging fairly. In the first type, the form of sharing can be compared with an arithmetic division, in which the identity of the terms is preserved, resulting in equality. The second way requires that the terms be equivalent, but not equal, resulting in proportionality. Injustice goes against this any of these ways of proceeding in relation to the other.

The virtue of being fair might be in accordance with what is due to each, or with what is suitable in certain situations and to people involved. The first is called distributive justice or equity, and the second commutative justice or equality.

In the health area, these justice criteria can be applied to operate an ethical analysis. Equitable attitudes can be considered as fair, in which resources and benefits are distributed unequally, but in conformity with the service users' needs. For example, should resources for primary, secondary and tertiary care be divided equally or equitably? Should the benefits and services of a region going through an epidemic process be planned and distributed in the same way as other services that maintain a normal care routine? Should more professionals be available to act in child care than in adult and elderly care (or vice-versa)? Should population from poor countries with health deficits and morbidities be preferred as research subjects because their lower life expectancy and impossibility of recovery?

Thus, justice criteria still is an important beacon in the judgment and valuation of situations 
involving the human being. Throughout history, we can see that the conception of justice acquires different nuances, but the valuation system of autonomy and respect for the subject (modern ethics), besides the Aristotelian system, is one of the pillars of ethical reflection in health. In this sense, the notion of people's dignity also gains importance. In conceptual terms, it originates in Kant's categorical notion that the human being must be respected as something important in itself, that is, due to the fact of being a person, (s)he gains an intrinsic value ${ }^{(3)}$.

Adding to the notion of justice proposed by Aristotle, as any attitude or action against the parameters of what is fair, the Kantian notion of people's dignity as valuable by themselves, makes possible to understand the idea of inequality and to do its linkage with the conception of poverty presented above.

Poverty and wealth can be considered results of a certain way of generating and distributing goods, with more capital accumulation and enjoyment opportunities for some countries and less or hardly any for others. The fact, for example, that health care services in developing countries tend to be precarious regarding to care needs and that, moreover, investments and amounts destined for this area are insufficient, give rise to ethical inquiries about the inequality issue of opportunities and living conditions, in comparison with the goods and resources that exist in developed countries.

Many specialists use the globalization phenomenon to justify the large gap between the rich and the poor in our times. We will not look further into this here but, for the sake of observation, it should be reminded that some countries are in a "state of severe poverty" and do not succeed to manage to minimally participate in the relations that characterize the globalized world, such as some African countries ${ }^{(4)}$.

\section{POVERTY AND RESEARCH: EXPLORATION}

In the last decade, in biomedical research, one of the main challenges has been the realization of clinical trials in poor nations, especially when these studies are coordinated and sponsored by rich countries or by the pharmaceutical industry. This polemics became important on the international agenda of research ethics due to the revelation of research carried out in some African and Asian countries in 1996 with North American funding, in which HIV-positive women were randomized in treatment groups with half doses of antiretroviral medication or in a control group with placebo. At that time, in clinical practice, the combination of antiretrovirals and other drugs was already being used to prevent vertical HIV transmission, which would ethically contraindicate, based on the Helsinki Declaration $^{(5)}$, the use of placebo in a control group. One justification for carrying out the studies in Asian and African countries was that they would not be approved in the USA, because of the existence of a known effective current treatment would not permit the inclusion of subjects in a control group with placebo. Moreover, it was alleged that, as the Asian and African countries where the study would be carried out were poor and did not have a good healthcare system, the women in that region usually did not receive any aids treatment and, hence, their inclusion in the placebo group would not expose them to a greater risk than they were already facing in their daily life. That is, poverty would justify a double ethical standard. Ethical requirements would be stricter for protocols developed in richer countries and lewder when the research is carried out in poorer countries or nations. People's or groups' vulnerability would no longer be a justification and motivation for their protection, through their non inclusion in the research or with an inclusion, but surrounded with measures to correct unfair or potentially unfairness-generating inequalities.

In research ethics, and even in clinical ethics, people's autonomy and vulnerability have been commonly treated through the application of the consent form and the information delivered to the subjects. However, in order to understand the complexity of human autonomy and vulnerability, there is a need to discern challenges that go beyond the relation between the researcher and the subject or the health professional and the healthcare service user. Active respect for people as autonomous subjects requires a critical analysis of the social conditions in with these people live. Interfering sociostructural factors that determine and condition people's life and health should be carefully understood and weighed. In fact, these factors end up defining the more limited sphere of human relationships. Although ontological, the expressions of human vulnerability and autonomy are devised for the social network. Thus, the debate about vulnerability in research ethics needs to be contextualized and its horizons need to 
be expanded, taking individual and collective dimensions of the vulnerable being into consideration.

"Vulnerability" and "being vulnerable" are not the same. Vulnerability refers to the anthropological dimension, which is essential in human existence. "Being vulnerable" means being susceptible to or in danger of suffering damage. Besides basic vulnerability, intrinsic in human existence and common to all human beings, some people are affected by unfavorable circumstances like poverty, lack of education, difficult geographical conditions, chronic or endemic diseases, lack of access to citizenship institutions or any other misfortunes that make them especially vulnerable. This socially determined vulnerability can be called "secondary" or "circumstantial", or also "susceptibility"(5).

In the context of this understanding, the idea of power relations between people, groups and nations is introduced. And, hence, the dynamic nature of vulnerability points out. And this vision constitutes the key for the emancipation of health service users and research subjects. Vulnerable people with unattended needs, with difficulties to access goods, services and accomplish their capacities find themselves more fragile in negotiations, which can be less fair and equalitarian, predisposing them to damage. A conception marked by the bipolar tendency of classifying and labeling people and groups as "vulnerable" and "non vulnerable", does not favor a space for the construction of user and subject emancipation, as it hides the dynamics of vulnerability, which is not a given state, but results from relations of domination and exploration. On the other hand, a broader comprehension that covers the social aspects of vulnerability derives from the positive obligation to make people's autonomy real through interventions aimed at reducing the vulnerability of persons as well as groups and populations ${ }^{(6)}$.

Research subjects' vulnerability is not restricted to a definition in terms of their age or cognitive, mental, legal capacity or to their ability for decision making and for signing the freely given and informed consent. The traditional view of consent charges the burden of the subject's vulnerability on the individual aspect only, as if the relation between the researcher and the subject did not occur in the framework of a complex social context that ends up influencing it.

The vulnerability of a person or a specific social group results from a set of not only individual, but also macro social, contextual, relational, political and organizational factors and aspects that determine people's level of susceptibility to risks as well as their capacity to cope with them and to make decisions about their life and health ${ }^{(6)}$. Hence, the focus of discussions on vulnerability cannot consider the fragilities, difficulties and lacks people experience as "natural, inherent characteristics" of these persons or the groups and nations they belong to. However, it should weigh the vulnerability amidst the sociostructural context people live in order to analyze and understand the set of factors and circumstances that determine and condition the vulnerable situation of people, groups and nations.

This broader approach of vulnerability proposes to assess the coexistence, synergy and conjunction of different elements and factors of different orders, amalgamated in the construction of individual and group vulnerability. Therefore, the interventions to reduce vulnerability cannot remain restricted to an individual answer or to one single and isolated action, but require the articulation of the different social actors involved and distinct actions, so as to favor a social response and interventions at different levels. This permits a broader and more precise perception of the specificities, singularities and differences that exist in the life of people and in the organization of society and that increase, stabilize or restrict alternative options for individual decision making. It also offers a range of more structured, articulated, broader and more appropriate answers to the complexity that shapes the vulnerability of people, groups and populations in society ${ }^{(6)}$.

Three levels can be proposed for assessment and intervention in the research subjects vulnerability ${ }^{(7)}$. The first level is the individual, which includes access to information, competence for decision making, right to freedom, right to privacy and confidentiality, quality of the researcher-subject relation, subjects' understanding of their rights, service alternatives and available diagnosis means and therapies.

A second level is programmatic and mainly refers to the institutions that regulate ethics in research involving human beings. Its coverage ranges from the existence of ethical rules or guidelines for research with human beings to the implementation and functioning of local and international commissions that assess and follow the ethical aspects involved in research and the use of subjects. 
A third level is social and includes the living conditions, social network and conflicts of interest involved in research with human beings. The living conditions cover poverty; education opportunities; educational development level; income distribution standards; social inequalities; social exclusions; organization and quality of health system; facilities and barriers for access to medical care; religious or cultural customs and power structures of local and group leaders. Social network support includes the community's view on biomedical research; the exclusion of certain social groups; support for social policies and laws to protect research subjects; existence of non governmental organizations to protect the rights of subjects and patients; subjects' access to the benefits that result from the research; return of the benefits to the community where the study was carried out. Conflicts of interest imply the relationship between pharmaceutical industry; colleges and scientific journals: acceptance for publication of articles with positive results only; sponsors' influence in the publication of research results; industrial sponsorship of biomedical research, journals, scientific events, researchers, basic and continued education activities and even of care activities at universities and university hospitals; high publication and production rates demanded by university assessment criteria.

Autonomy and power are not the same, although autonomy constitutes an expression of power. Sociocultural vulnerability appears in the unequal and excluding forms in which the production and reproduction power is sociologically distributed in societies. Power and vulnerability go hand in hand. The contemporary cultural ethos, fascinated by power, tries to forget about the human condition of vulnerability and, as a result, does not know how to handle it. The hiding of vulnerability leads to the coverup of its social causes. This attempt to hide the social causes of vulnerability turns autonomy into a discourse

\section{REFERENCES}

1. Ugá VD. A categoria pobreza nas formulações de política social do Banco Mundial. Sociol Polit [online] 2004 Nov [cited 2007 May 12]; n. 23 [about 7 p.] Available form: http:// www.scielo.br/scielo.php?script $=$ sci_arttext\&pid=S010444782004000200006\& Ing=pt\& $n r m=i s o>$.

2. Aristóteles. Etica a Nicômaco. In: Os Pensadores Aristóteles II. São Paulo (SP): Abril Cultural; 1979. p.121138. to hold victims accountable for their own injuries. The bioethics developed within Latin American paradigms has taken the challenges of social vulnerability and its more profound causes seriously, with a sound consideration to the consistent construction of autonomy. Thus, it has fought against the ethos of individualism that pulverizes the reason of interpersonal responsibility, tames the capacity to get indignant about inequities and reduces ethics to defensive aspects, inhibiting its affirmative and creative dynamism ${ }^{(8)}$.

\section{FINAL CONSIDERATIONS}

To raise one last question - but without closing off the debate - it should be taken into account that, in terms of advances in biomedical sciences to improve knowledge that benefits people's health, tests need to be applied (according to accepted protocols) to humans. Therefore, it is pertinent to use the Aristotelian principle of justice as reciprocity ${ }^{(9)}$, which, for this discussion, requires that research subjects receive the benefits due to the fact that they are participating. It could not be justified that a subjectpatient who received placebo would not receive the drug whose therapeutic effect was approved by the study at the end of the research. It could not be justified either that a subject who benefited from the medication would no longer receive it, due to the fact that it is not sold yet in the country. Moreover, when commercially available, the price charged is usually prohibitive for people who served research subjects. Exploration occurs when rich or powerful people or agencies make use of other people's poverty, weakness or dependence to achieve their own goals. Poverty is questioning us. It calls for decisive answers and committed actions to rescue human beings' dignity and defend the life that is threatened and the ful citizenship for all.

3. Ribeiro, CRO. O conceito de pessoa na perspectiva da bioética secular: uma perspectiva a partir do pensamento de Tristram Engelhardt. [Tese doutorado]. São Paulo (SP): Faculdade de Saúde Pública/USP; 2002.

4. Pogge T. Global Justice as moral issue. Ethic@ 2005 junho; 4(1):1-6.

5. Kottow MH. Comentários sobre bioética, vulnerabilidade e proteção. In: Garrafa V, Pessini L, organizadores. Bioética: poder e injustiça. São Paulo: Loyola/Centro Universitário São Camilo/Sociedade Brasileira de Bioética; 2003. p.71-8. 
6. Zoboli ELCP, Pupo LR, Fracolli LA. Buscando um novo referencial para compreensão da vulnerabilidade dos sujeitos de pesquisa. Anais do VI Congresso Brasileiro de Bioética / I Congreso de Bioética del Mercosur e Fórum da Redbioética / UNESCO; 2005 Setembro 193-195; Foz do Iguaçu, Brasil: 2005.

7. Zoboli ELCP. Vulnerability in biomedical research: a framework for analysis. In: Häyry M, Takala T, KellyHerissone $P$, editors. Ethics in biomedical research: international perspectives. Amsterdan-New York; 2007. p. 167-80.

8. Anjos MF. A vulnerabilidade como parceira da autonomia. Rev Bras Bioética 2006; 2: 173-86.

9. Aristóteles. Etica a Nicômaco. In: Os Pensadores Aristóteles II. São Paulo (SP): Abril Cultural; 1979. p.127. 